\title{
Assessment of Soil Erosion Rates Using Revised Universal Soil Loss Equation (RUSLE) and GIS in Bačka (Serbia)
}

\author{
Nikola Milentijević1, Miloš Ostojić ${ }^{2}$ Renata Fekete $^{2}$, Kristina Kalkan², Dušan Ristić1*, \\ Nikola R. Bačević1, Vladica Stevanović1, Milana Pantelić \\ ${ }^{1}$ University of Priština in Kosovska Mitrovica, Faculty of Sciences and Mathematics, Department of Geography, \\ Lole Ribara 29, 38220 Kosovska Mitrovica, Serbia \\ ${ }^{2}$ University of Novi Sad, Faculty of Sciences, Department of Geography, Tourism and Hotel Management, \\ Trg Dositeja Obradovića 3, 21000 Novi Sad, Serbia
}

Received: 20 January 2021

Accepted: 4 April 2021

\begin{abstract}
Soil erosion assessment enables the identification of manifested soil erosion categories, their spatial distribution and the relationship between soil erosion and land use patterns. The integrated approach of the RUSLE method and GIS tools was used in estimating soil erosion rates in Bačka (Serbia). Previous research of soil erosion intensity in the study area was last performed 50 years ago. The spatial distribution of the calculated erosive factors shows the diversity of erosive conditions. The results indicate that the average annual soil loss is from 0 to $28.6 \mathrm{t} \mathrm{ha}^{-1} \mathrm{yr}^{-1}$. The soil erosion is particularly pronounced in the area of the Titel loess plateau (up to $28.6 \mathrm{t} \mathrm{ha}^{-1} \mathrm{yr}^{-1}$ ). The results indicate the diversity of the erosion rates depending on the land use. Multiple correlation indicates that the LS factor has the largest effect on erosion (correlation coefficient 1). The results in this paper can be used in planning future conservation measures, especially if the recent field measurements of soil erosion are added. This research is also important since the RUSLE method represents a new approach in determining the soil erosion intensity.
\end{abstract}

Keywords: soil erosion, RUSLE and GIS, land use, conservation measures, Bačka

\section{Introduction}

Soil erosion is a natural process that refers to the removal of the upper layers of the soil by the action of various erosive agents such as water, wind and gravity. This phenomenon represents a serious environmental

*e-mail: dušan.ristic@pr.ac.rs problem that was recognized in the 1930s [1]. This process is in most cases caused by natural factors [2], although it can be accelerated by anthropogenic activities such as intensive agriculture, inadequate land use, deforestation and tillage on steep slopes [3]. Agricultural land is particularly endangered, which records the loss of the fertile layer, more pronounced surface water runoff and reduction of water reserves used by vegetation [4]. It was estimated that $33 \%$ of land 
worldwide is affected by land degradation (more than 4,900 million ha) [5]. The average global erosion rate is $2.4 \mathrm{t} \mathrm{ha}^{-1} \mathrm{yr}^{-1}$, while this rate is lower at the national level $\left(\sim 1.4 \mathrm{t} \mathrm{ha}^{-1} \mathrm{yr}^{-1}\right)$ [6]. The potential increase in global soil erosion rate is caused by the expansion of arable land. The largest increases in erosion intensity are predicted for sub-Saharan Africa, South America, and Southeast Asia [7].

The first systematic observations of erosive processes in Bačka were performed by R. Lazarević from 1966 to 1971. Although in AP Vojvodina erodible terrains occupy $72.29 \%$ of the territory, the erosive process mainly belongs to the category of very slight erosion [8]. Based on the dominant geomorphological agent, aeolian erosion is expressed in the north of Bačka (Subotica-Horgoš sandstone) [9]; possible pluvial erosion can occur in the Pannonian Basin (including parts of Bačka) [10]; fluvial erosion is expressed on the large border rivers of Bačka (Danube and Tisza), as well as larger rivers and their tributaries in Bačka [11]. In recent years, the intensity of erosion of the Titel loess as a small part of Bačka has been investigated. It was determined that soil erosion is the dominant process, while the estimated values of soil loss ranged from $-1.58 \mathrm{t} \mathrm{ha}^{-1} \mathrm{yr}^{-1}$ to $-10.60 \mathrm{tha}^{-1} \mathrm{yr}^{-1}$, which classifies the erosive process as moderate [12].

Numerous widespread and popular empirical models have been developed that serve to assess the intensity of erosion: Erosion Potential Method - EPM [13], The Universal Soil Loss Equation - USLE [14], Modified Universal Soil Loss Equation - MUSLE [15] and Revised Universal Soil Loss Equation - RUSLE [16]. The RUSLE method is suitable for determining the rate of erosion in agricultural regions of lowland type such as Bačka with a slope ranging from 3 to $18 \%$ [17]. The subject of this paper is an integrated approach of RUSLE method and GIS techniques in estimating the rates of soil erosion in Bačka (Serbia). The intensity of soil erosion in Bačka was estimated by the EPM method [18] but not yet by applying the RUSLE method. With this approach, it is possible in future research to compare the results obtained using the RUSLE method with the EPM method [19]. This fact has importance since the field research of soil erosion in the study area dates back to 1970's [8].

Bačka is located in the southern part of the Pannonian Plain and the northwestern part of the Autonomous Province of Vojvodina and the Republic of Serbia. The natural border of Bačka consists of the rivers: the Tisza towards Banat (eastern border of Bačka), the Danube towards Srem (southern border of Bačka) and the Danube towards the neighboring state of Croatia (partly in the south and west). The border with Hungary belongs to artificial borders. This border intersects and connects the largest rivers of the Pannonian Plain - the Danube and the Tisza [20].

Digital elevation models (DEM) are mainly used in geomorphological research, relief shape classification, geomorphometry and represent a significant factor in environmental modeling [21]. Based on the DEM model, the absolute heights of the terrain vary from $61 \mathrm{~m}$ to $141 \mathrm{~m}$ (Fig. 1). The relief uniformity of the area is mostly disturbed by the Subotica-Horgoš sandstone (north of Subotica, Palić and Horgoš, extending deep into Hungary towards the north). On the territory of Bačka, its absolute height ranges from $100 \mathrm{~m}$ to $141 \mathrm{~m}$. The area of Bačka is $8,956 \mathrm{~km}^{2}$ [22], while the area obtained by vectorization using GIS tools is a research area of $8,786.23 \mathrm{~km}^{2}$ with 990,364 inhabitants [23]. Bačka represents a significant agricultural region of Autonomous Province of Vojvodina and the Republic of Serbia, with 591,332 ha $(37.6 \%)$ of used agricultural land and only 23,579 ha $(1.5 \%)$ of unused agricultural land [24].

\section{Materials and Methods}

\section{RUSLE Method}

A widely used model for estimating soil erosion intensity is the RUSLE method, developed by the Department of Agriculture (USA) for the purpose of soil conservation and land-use planning. This method is a modification of the USLE method most commonly used to predict the average rate of agricultural land loss. The RUSLE method is often used to assess the average soil erosion, which demands the set of proposed measures in order to control the erosion intensity in different land uses [25]. The disadvantages of the RUSLE empirical model are presented through several problems: a) poor availability of reliable longterm modeling data; b) inability to take into account soil erosion originating from gullies and transported eroded material; d) prediction of potential sediment deposition [26]. Despite its disadvantages, the RUSLE method [27] remains a popular tool for determining the intensity of soil erosion due to the simple data entry and the simple model structure. The ArcGIS 10.7 software was used to generate maps using the RUSLE method. The integration of the RUSLE method with the GIS tool aims to more efficiently predict the intensity of soil erosion and its spatial distribution. The RUSLE method is represented by the Eq. 1 [28]; (Fig. 2):

$$
\mathrm{A}=\mathrm{R} * \mathrm{~K} * \mathrm{~L} * \mathrm{~S} * \mathrm{C} * \mathrm{P}
$$

...where A - average annual soil loss per area unit ( $\mathrm{t} \mathrm{ha} \mathrm{h}^{-1}$ $\left.\mathrm{yr}^{-1}\right), \mathrm{R}$ - rainfall erosivity factor $\left(\mathrm{MJ} \mathrm{mm} \mathrm{ha} \mathrm{mm}^{-1} \mathrm{hr}^{-1}\right.$ ), $\mathrm{K}$ - soil erodibility factor ( $\mathrm{t}$ ha h $\mathrm{MJ}^{-1} \mathrm{~mm}^{-1}$ ), $\mathrm{L}$ - slope length factor, $\mathrm{S}$ - slope steepness factor, $\mathrm{C}$ - land use and $\mathrm{P}$ - support and conservation practices factor.

\section{Rainfall Erosivity Factor (R)}

The recorded monthly precipitation values were used in order to determine the mean annual value of the $\mathrm{R}$ factor [29]. Data from available meteorological 


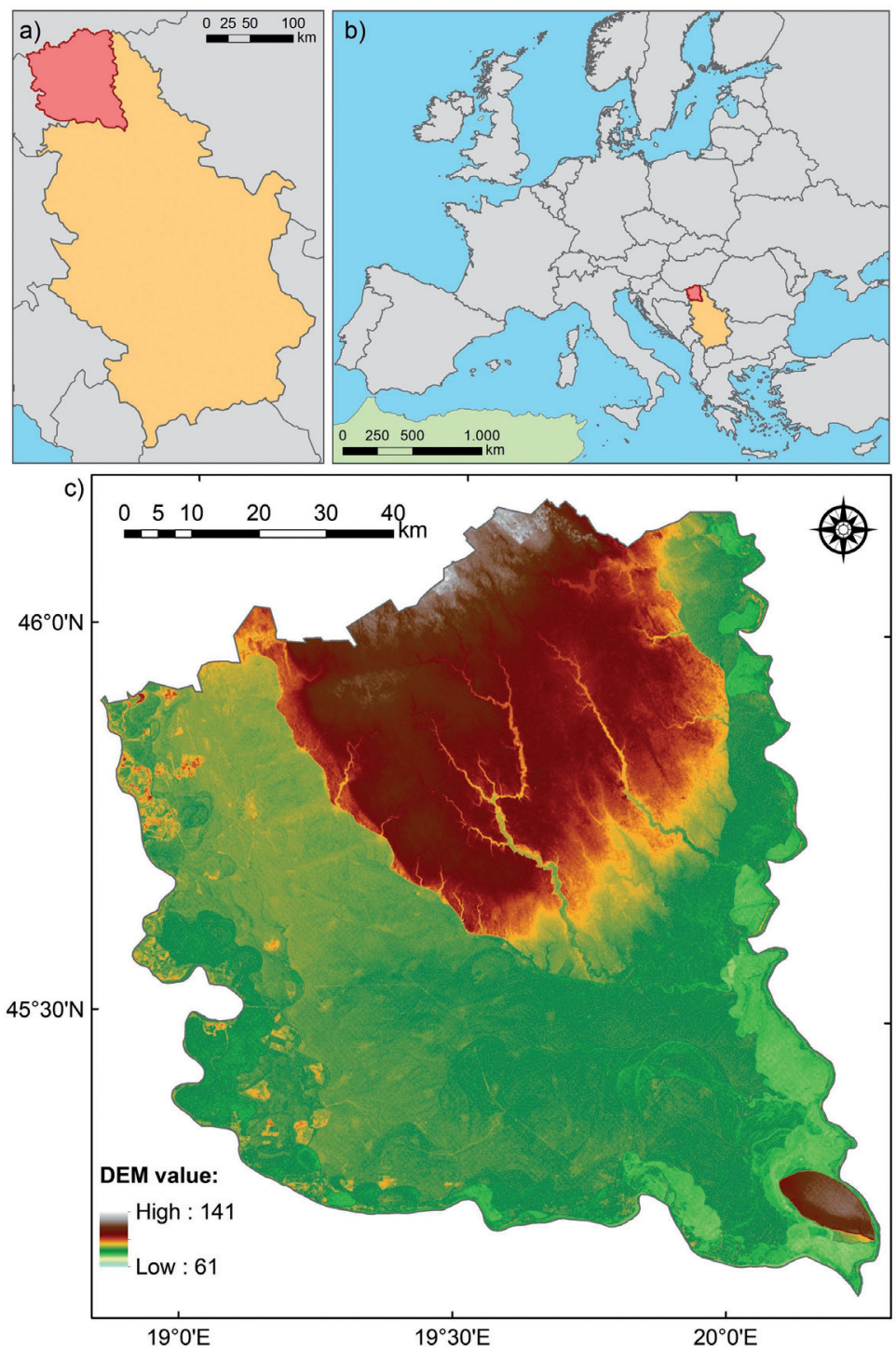

Fig. 1. Location map of Bačka in the Republic of Serbia a), in Europe b) and Digital Elevation Model (DEM) of study area.

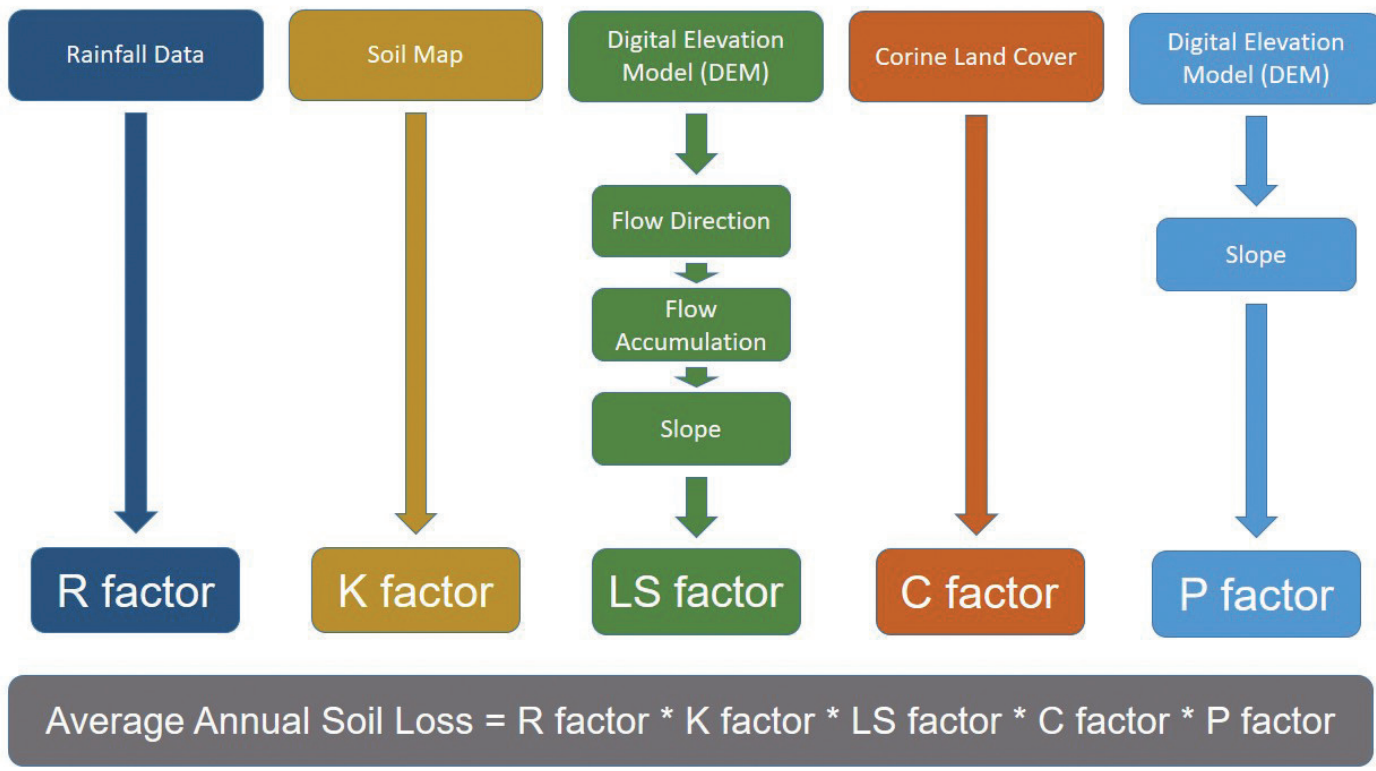

Fig. 2. Flowchart of applied methodology. 
stations (Novi Sad, Sombor, Bečej and Palić) were used in order to determine the average values of the $\mathrm{R}$ factor and analyzed for a thirty-year period (1981-2010). The R factor was determined based on the modified Fournier index (F). This index takes into account data on monthly and annual precipitation as well as empirical formulas that indicate the relation between $\mathrm{F}$ and $\mathrm{R}$ (Eq. 2):

$$
\mathrm{F}=\sum_{\mathrm{I}=1}^{12} \frac{\mathrm{p}_{\mathrm{i}}^{2}}{\mathrm{P}}
$$

...where, $p_{i}$ represents the monthly amount of precipitation for the month $i(\mathrm{~mm})$, and $P$ represents the annual precipitation $(\mathrm{mm})$. An equation was proposed for determining the value of R [29] (Eq. 3):

$$
\mathrm{R}=0.739 * \mathrm{~F}^{1.847}
$$

The map of rainfall erosivity factor was obtained using IDW (Inverse Distance Weighting) interpolation technique where unknown values were calculated based on the values of known points [30]. The IDW interpolation is based on the assumption that the climatic value at an unsampled point $z(x)$ is a distance-weighted average of the climatic values at nearby sampling points $z(x 1), z(x 2), \ldots, z(x n)$. Climatic values are more similar at closer distances, so the inverse distance (1/di ) between $z(x i)$ and $z(x)$ is used as the weighting factor (Eq. 4):

$$
\mathrm{z}(\mathrm{x})=\frac{\sum_{\mathrm{i}=1}^{\mathrm{n}} \mathrm{z}\left(\mathrm{x}_{\mathrm{i}}\right) \mathrm{d}_{\mathrm{ij}}^{-\mathrm{r}}}{\sum_{\mathrm{i}=1}^{\mathrm{n}} \mathrm{d}_{\mathrm{ij}}^{-\mathrm{r}}}
$$

...where $z(x)$ is the predicted value, $z\left(x_{i}\right)$ is the climatic value at a neighbouring weather station, $d_{i j}$ is the distance between $z(x)$ and $z(x)$, and $r$ is an empirical parameter [31].

\section{Soil Erodibility Factor (K)}

Soil erodibility factor $(\mathrm{K})$ is a quantitative indicator that serves as a measure of soil susceptibility to erosion through precipitation and runoff [25]. It is an empirical measure that indicates the characteristic texture of the soil. Soil texture is a major factor which influences the intensity of soil erosion, along with its structure, organic matter content, and water permeability [32]. Land types in the study area were identified based on the land map [33]. Each type of land is assigned a certain value of $\mathrm{K}$ (Table 1). Factor K was estimated based on the soil texture classification [34], taking into account that the content of organic matter is $<4 \%$.

\section{Slope Length and Slope Steepness Factor (LS)}

The topographic factor (LS) includes two components: the slope length factor (L) and the slope steepness factor (S). The LS factor was calculated using
Table 1. Value of $\mathrm{K}$ based on soil texture with the assumption that the organic matter content is $<4 \%$.

\begin{tabular}{|c|c|}
\hline Soil texture & K value \\
\hline sand & 0.02 \\
\hline loamy sand & 0.04 \\
\hline sandy loam & 0.13 \\
\hline loam & 0.3 \\
\hline muddy loam & 0.38 \\
\hline mud & 0.6 \\
\hline sandy clay-loam & 0.2 \\
\hline clay-loam & 0.3 \\
\hline muddy clay-loam & 0.32 \\
\hline sandy clay & 0.14 \\
\hline muddy clay & 0.26 \\
\hline clay and compacted clay & 0.22 \\
\hline
\end{tabular}

DEM at a resolution of $25 * 25 \mathrm{~m}$ and an extension in the ArcGIS (Spatial Analyst extension) software. The L factor was calculated based on the following equation proposed by using a raster calculator [35] (Eq. 5):

$$
L=\left(\frac{\lambda}{22.13}\right)^{\mathrm{m}}
$$

...where $\lambda$ horizontal projected slope length, while $m$ is the slope length exponent. The $\mathrm{S}$ factor serves as a measure of slope steepness and it is calculated using a raster calculator and a defined relations [4] (Eq. 6,7):

$$
\begin{aligned}
& S=10.8 \sin \theta+0.03 \text { for slope }<9 \% \\
& S=16.8 \sin \theta-0.50 \text { for slope } \geq 9 \%
\end{aligned}
$$

...where $S$ is slope steepness factor and $\theta$ slope angle in degree.

\section{Land Use (C) and a Conservation Practice Factor (P)}

This paper determines the $\mathrm{C}$ factor on the basis of the CORINE Land Cover database in the scale of 1:100000 [36]. For the needs of the paper, a satellite image for 2018 was used (in a resolution of $10 \mathrm{~m}$ ). Based on the obtained data, changes in the condition of the land cover in the research area were analyzed. $\mathrm{C}$ factor values were assigned to all land use types based on the values cited in the literature [37]. The research area was classified into 24 land use categories divided into 5 basic classes (Table 2). Agricultural land occupies the largest share $(84.9 \%)$, followed by forestland $(6.5 \%)$, artificial areas $(5.9 \%)$, while the smallest areas are occupied by water surfaces $(2.0 \%)$ and uncategorized areas $(0.7 \%)$. 
Table 2. C factor values for different land use in Bačka [37].

\begin{tabular}{|c|c|c|}
\hline Land use & C factor & Area $\left(\mathrm{km}^{2}\right)$ \\
\hline Artificial surfaces & 1.0 & 527.08 \\
\hline Agricultural land & 0.28 & 7575.61 \\
\hline Forestland & 0.004 & 575.89 \\
\hline Uncategorized areas & 0.00 & 65.26 \\
\hline Water surfaces & 0.00 & 182.95 \\
\hline
\end{tabular}

The conservation practice factor $(\mathrm{P})$ represents "the ratio between the soil loss and the specific practice of supporting the given loss by treating it with inclination and slope tillage" [35]. The values of conservation practice factor $(\mathrm{P})$ vary in the range from 0 to 1 . The values of the $\mathrm{P}$ factor close to zero indicate good conservation practice, while the unit value indicates inadequate measures in the fight against erosion. Together with the $\mathrm{C}$ factor, this is a parameter in the RUSLE method, extremely susceptible to dynamic changes [38].

\section{Multiple Correlation Analysis}

Multiple correlation is an analytical procedure that determines how multiple independent variables affect a single dependent variable. It is necessary to calculate the correlation coefficients between each pair of variables we take into consideration. The obtained coefficients must be included in the equation used for calculating the multiple correlation. The equation for calculating multiple correlation when observing the influence the two independent variables have on the third, dependent one, is the following (Eq. 8):

$$
R=\frac{\sqrt{r_{Y X_{1}}^{2}+r_{Y X_{2}}^{2}-2 r_{Y X_{1}} * r_{Y X_{2}}}}{\sqrt{1-r_{X_{1 X_{2}}}^{2}}}
$$

The independent variables are denoted by $X_{1}$ and $X_{2}$, while the dependent variable is denoted by $Y$. The multiple correlation coefficient ranges from 0 to 1 ; higher values indicate that the dependent variable is highly dependent on the independent one, a value of 1 indicates a strong correlation, while a value close to or equal to zero implies a weak correlation. In order to obtain as accurate results as possible, it is necessary to use a sample with multiple values of variables [39].

\section{Results and Discussion}

\section{Estimation of Soil Erosion Intensity Using RUSLE Method}

Each of the individual factor from RUSLE equation was derived separately (Fig. 3). Rainfall erosivity factor (R) values for the 30-year period vary from 211.03 to 255.2 , with an average value of
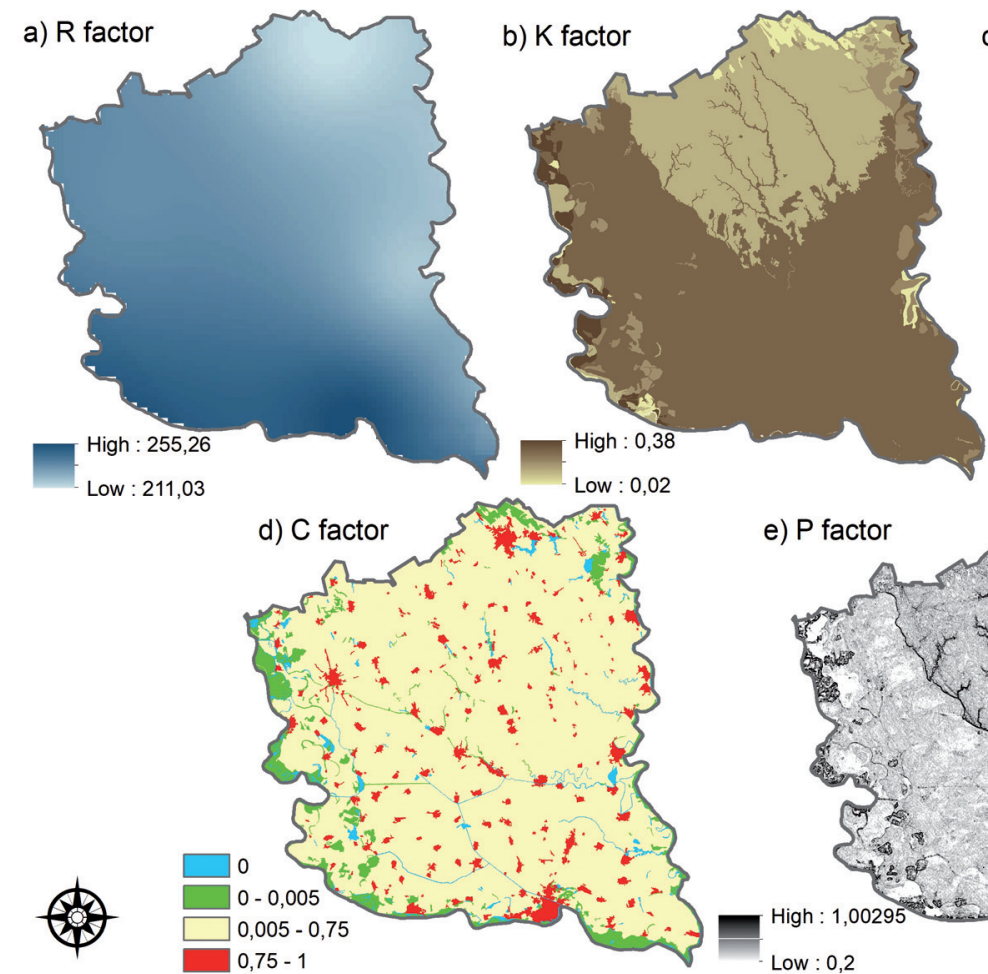

e) $P$ factor

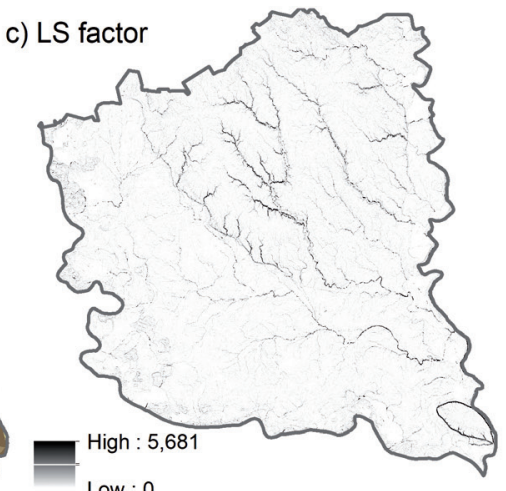

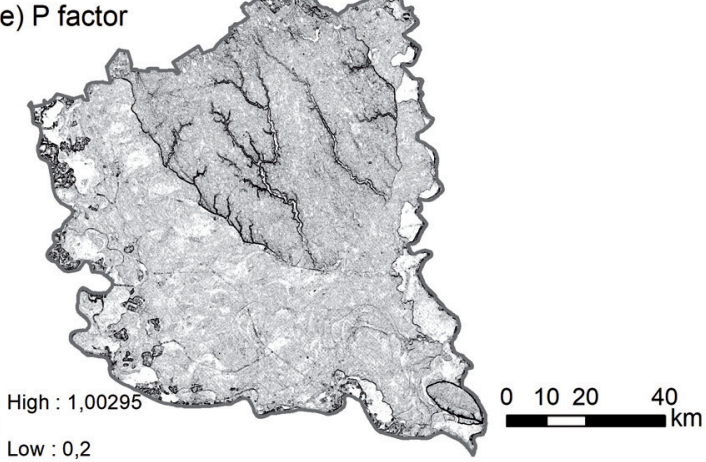

Fig. 3. Spatial distribution of rainfall erosivity factor a), soil erodibility factor b), slope length and slope steepness factor c), cover and management factor d) and e) support and conservation practices factor in study area. 
232.07 MJ mm ha ${ }^{-1} \mathrm{~h}^{-1} \mathrm{yr}^{-1}$. Low values of the $\mathrm{R}$ factor are present in the northeastern parts of Bačka, while the southwestern parts show higher values. The detected values in the southwest can be explained by the influence of orographic relations, i.e. the proximity of Fruška Gora. In general, the erosive potential of this factor and its spatial distribution are related to the pluviometric regime. Similar precipitation patterns in the spatial distribution of annual precipitation totals in the area of Bačka and Vojvodina were noticed [40].

The values of soil erodibility $(\mathrm{K})$ range from 0.02 to 0.38 , with an average value of $0.243 \mathrm{t}$ ha $\mathrm{h} \mathrm{MJ}^{-1} \mathrm{~mm}^{-1}$. Higher values of $\mathrm{K}$ factor were recorded in the alluvial plains of the Danube and part of the Tisza. Slightly lower values were registered in the south, as well as in the eastern and western parts of Bačka. The lowest values are present in the north of Bačka, but also in "oases" along the rivers Tisza and Danube. The spatial distribution of this factor interacts with the texture and dominant soil types. Higher values of this factor correspond to alluvial soils, marsh black soils, marsh soils and wetlands formed on marsh loess and alluvial sediment. These lands are among the potentially most fertile, but due to high waters they are often flooded, which reduces their solvency. Slightly lower values of the factor in relation to the previous soil types are shown by the extremely fertile chernozem formed on the land loess within the loess plateaus and terraces of Bačka [41]. The minimum values of $\mathrm{K}$ factor are spatially related to the sand formations of the Subotica-Horgoš sandstone, where there are initial, poorly developed soils (regosol) formed on Aeolian origin sand, less often on loess [42].

The minimum value of the LS factor is 0 , while the maximum value is 5.681; with an average value of 1.92. The spatial variability of this factor shows that the lowest values are characteristic of the hypsometrically lowest parts of the Bačka terrain. The central parts of Bačka represent a significantly dissected terrain, which is a consequence of the dense river network represented by the Krivaja River, Mostonga River with tributaries as well as the canal network (the Great Bačka Canal and the Danube-Tisza-Danube Canal). This is the cause of the pronounced value of the LS factor. The highest values of this factor were recorded on the Titel loess plateau.
The values of land use $(\mathrm{C})$ are in the range of $0-1$, with an average value of 0.296 . The research area consists of 24 classes of land cover, where there are 5 basic classes, which are important for soil erosion: a) agricultural land $(84.9 \%)$, b) areas covered by forest $(6.5 \%)$, c) urbanized areas $(5.9 \%)$, d) water areas $(2.0 \%)$ and e) uncategorized areas $(0.7 \%)$. The spatial distribution of this factor is extremely heterogeneous. The highest values of $\mathrm{C}$ factor determine a significant part of the territory of Bačka, which is important in agricultural production. The lowest values of the factors refer to water areas (alluvial plains of the Danube, Tisza and their abandoned meanders; lakes of fluvial and aeolian origin). The conservation practice factor (P) varies from 0.2 to 1.00295 , with a mean value of 0.219 . Most of the research areas are characterized by higher $\mathrm{P}$ factor values, which indicates inadequate erosion control. For this reason, it is necessary to take appropriate anti-erosion measures. Higher factor values were recorded in the valleys of larger Bačka rivers and their tributaries; as well as on the edges of the Titel loess plateau.

Table 3 shows the average annual soil loss (A) in the area of Bačka in the interval of $0-28.6 \mathrm{t} \mathrm{ha}^{-1} \mathrm{yr}^{-1}$, with an average value of $0.007022 \mathrm{t} \mathrm{ha}^{-1} \mathrm{yr}^{-1}$. The results indicate that $99.98 \%$ of the territory of Bačka is in the category of very slight erosion $\left(0-2 \mathrm{t} \mathrm{ha}^{-1} \mathrm{yr}^{-1}\right)$. In the category of slight erosion is $0.01 \%\left(2-10 \mathrm{tha}^{-1} \mathrm{yr}^{-1}\right)$. Moderate erosion is present at $0.000682 \%(20-28.6 \mathrm{t}$ $\left.\mathrm{ha}^{-1} \mathrm{yr}^{-1}\right)$, while severe erosion is present at $0.0000009 \%$ of Bačka terrain. The class of extreme severe erosion $\left(>28.6 \mathrm{t} \mathrm{ha}^{-1} \mathrm{yr}^{-1}\right)$ is not represented.

In the spatial distribution of soil erosion intensity, it can be noticed that in the largest part of the territory of Bačka, there are no erodible conditions that correspond to the categories II-V of soil erosion intensity (Fig. 4). Low-intensity soil erosion is present in larger river valleys of Bačka (e.g. Mostonga, Krivaja). The highest estimated average rates of soil erosion (28.6 $\left.\mathrm{t} \mathrm{ha}^{-1} \mathrm{yr}^{-1}\right)$ was recorded on the marginal parts of the Titel loess plateau. The Titel loess plateau $\left(94 \mathrm{~km}^{2}\right)$ is located in the southeast of Bačka, at the confluence of the Tisza and the Danube. It owes its elliptical form to the erosive work of the Tisza and the Danube, as evidenced by the steep sections in the northeast and east, where the erosive process still occurs. Particularly important is

Table 3. Area under different categories of soil erosion in Bačka.

\begin{tabular}{|c|c|c|c|c|}
\hline Erosion categories & Rate of erosion $\left(\mathrm{t} \mathrm{ha}^{-1} \mathrm{yr}^{-1}\right)$ & Area $\left(\mathrm{km}^{2}\right)$ & Area (ha) & Area $(\%)$ \\
\hline Very slight & $0-2$ & 8786.23 & 878623.29 & 99.981679 \\
\hline Slight & $2-10$ & 1.53 & 153.99 & 0.017410 \\
\hline Moderate & $10-20$ & 0.06 & 6.21 & 0.000682 \\
\hline Severe & $20-28.6$ & 0.008 & 0.81 & 0.000009 \\
\hline Extreme severe & $>28.6$ & $/$ & $/$ & $/$ \\
\hline & & 8787.84 & 878784.3 & 100.00 \\
\hline
\end{tabular}




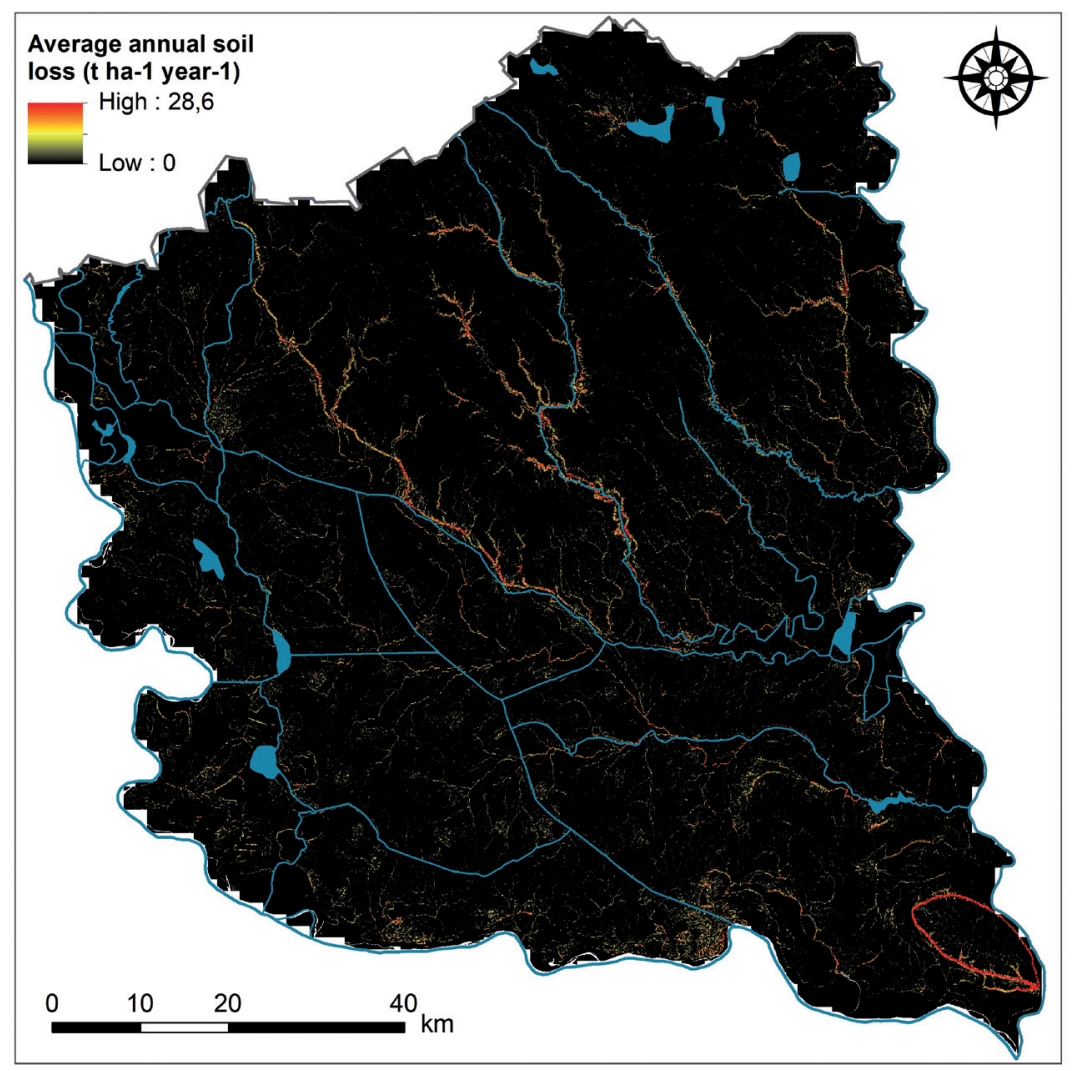

Fig. 4. Spatial distribution of average annual soil loss $\left(\mathrm{t} \mathrm{ha}^{-1} \mathrm{yr}^{-1}\right)$ in Bačka according to RUSLE method and GIS techniques.

the $60 \mathrm{~m}$ high and steep section above the Tisza, which was created by cutting and clearing the forest [43].

The analyzed data indicate very slight erosion rates; however in the relation between the soil erosion categories and land use, there are different erosive patterns (Table 4). In the category of very slight erosion $\left(0-2 \mathrm{t} \mathrm{ha}^{-1} \mathrm{yr}^{-1}\right), 83.73 \%$ is cultivated land. Very slight erosion affects $6.50 \%$ of forestland and $5.91 \%$ of land under artificial (urbanized) areas. Slight erosion $\left(2-10 \mathrm{t} \mathrm{ha}^{-1} \mathrm{yr}^{-1}\right)$ is expressed on $58.22 \%$ of cultivated areas and $39.04 \%$ of artificial areas. Moderate erosion
(10-20 $\left.\mathrm{t} \mathrm{ha}^{-1} \mathrm{yr}^{-1}\right)$ endangers $48.57 \%$ of arable land and $42.86 \%$ of artificial areas. Category of moderate erosion also affected $8.57 \%$ of the water surfaces of Bačka. Severe erosion (20-28.6 $\left.\mathrm{t} \mathrm{ha}^{-1} \mathrm{yr}^{-1}\right)$ especially affects cultivated land $(55.56 \%)$ and artificial areas $(44.44 \%)$. The category of extreme severe erosion $\left(>28.6 \mathrm{t} \mathrm{ha}^{-1} \mathrm{yr}^{-1}\right)$ is not represented on this area. A favorable circumstance is the fact that other categories of land use (grassland, forestland, orchards and vineyards) are not endangered by II, III and IV category of erosion. These surfaces have a significant impact on

Table 4. Percentage of soil erosion category under different land use types in Bačka.

\begin{tabular}{|c|c|c|c|c|c|}
\hline \multirow{2}{*}{ Land use types } & \multicolumn{5}{|c|}{ Soil erosion categories and rates of soil erosion $\left(\mathrm{t} \mathrm{ha}^{-1} \mathrm{yr}^{-1}\right)$} \\
\cline { 2 - 6 } & Very slight & Slight & Moderate & Severe & Extreme severe \\
\cline { 2 - 6 } & $0-2$ & $2-10$ & $10-20$ & $20-28.6$ & $>28.6$ \\
\hline Artificial surfaces & 5.91 & 39.04 & 42.86 & 44.44 & $/$ \\
\hline Arable land & 83.73 & 58.22 & 48.57 & 55.56 & $/$ \\
\hline Orchards and vineyards & 0.35 & 0.00 & 0.00 & 0.00 & $/$ \\
\hline Grasslands & 1.18 & 1.17 & 0.00 & 0.00 & $/$ \\
\hline Forestland & 6.50 & 0.64 & 0.00 & 0.00 & $/$ \\
\hline Wetlands & 0.66 & 0.00 & 0.00 & 0.00 & $/$ \\
\hline Water surfaces & 1.68 & 0.93 & 8.57 & 0.00 & $/$ \\
\hline Total & 100.00 & 100.00 & 100.00 & 100.00 & $/$ \\
\hline
\end{tabular}


Table 5. Correlation coefficients between annual soil loss (E) and erosive parameters (R, LS, C, P)*.

\begin{tabular}{|c|c|c|c|c|c|}
\hline & R & LS & C & P & E \\
\hline Rainfall Erosivity Factor (R) & 1 & $/$ & $/$ & $/$ & $/$ \\
\hline Slope Length and Steepness Factor (LS) & -0.07 & 1 & $/$ & $/$ & $/$ \\
\hline Cover and Management Factor (C) & 0.83 & 0.50 & 1 & $/$ & $/$ \\
\hline Support and Conservation Practices Factor (P) & 0.90 & -0.50 & 0.50 & 1 & 1 \\
\hline Annual Soil Loss (E) & -0.07 & 1 & 0.50 & -0.50 & 1 \\
\hline
\end{tabular}

the reduction of soil erosioInfluence of erosive factors on average soil loss rates

The detected distribution of soil loss is the result of interaction between erosive factors. The statistical relationship between the variety of erosive factors and erosion dynamics shows statistically significant trends occurring between certain parameters and erosion intensity (Table 5).

The influence of erosive parameters on the intensity of soil erosion was determined by the multiple correlation coefficient. According to the results (Table 5) there is a strong correlation between the erosion intensity (E) and the LS factor (the correlation coefficient is 1). In addition, a strong correlation was expressed between $\mathrm{R}$ and $\mathrm{C}$ factor (correlation coefficient 0.83 ) as well as $\mathrm{R}$ and $\mathrm{P}$ factor (correlation coefficient 0.90 ).

The presented results are compared to the erosion map of Socialist Republic of Serbia (1983) and the field observations from 1966 to 1971 [44]. It is estimated that soil erosion intensity in Bačka did not change significantly compared to direct field measurements. At the regional level, the obtained results indicate that in selected case studies the erosive process is classified as: a) in the Besnica valley in Slovenia the rate of soil erosion averages $36 \mathrm{ha}^{-1} \mathrm{yr}^{-1}$ with a decrease in topographic area of $2.6 \mathrm{~mm}$ per year [45]; b) $90 \%$ of the territory of Macedonia belongs to the I-III category of erosion, while in $30 \%$ of the territory of Bulgaria the potential risk of erosion is high [46]; c) about $47 \%$ of the Bosnia and Herzegovina belongs to the category of very slight erosion [47]; d) the Dubračina basin (Croatia) belongs to the category of slight erosion [48], e) the intensity of erosion in Miocki potok (Montenegro) was quantified as moderate [49]. Most of the Pannonian Plain within the borders of Hungary shows a category of very slight erosion [50]. The reduction was indicated in the average rate of soil erosion (up to $0.28 \mathrm{t} \mathrm{ha}^{-1} \mathrm{yr}^{-1}$ ) [51]. These values are similar when compared to the low average values of soil erosion in Bačka.

\section{Conclusions}

Based on the applied model, the paper analyzes the erosion factors, the average rates of soil erosion and its spatial distribution, as well as the land use class affected by the appropriate erosion categories. The following conclusions are highlighted and summarized:

a) due to the fact that Bačka occupies a significantly large area, there is heterogeneity of erosive factors;

b) the average annual soil loss in Bačka ranges from 0 to $28.6 \mathrm{t} \mathrm{ha}^{-1} \mathrm{yr}^{-1}$, with an average value of $0.007022 \mathrm{tha}^{-1} \mathrm{yr}^{-1}$;

c) the largest part of the territory of Bačka is characterized by conditions of very slight erosion, with the exception of larger river valleys, and especially the Titel loess plateau;

d) in relation to the land use, erosion of I, II, III and IV intensity especially puts agricultural and artificial areas in danger;

e) multiple correlation analysis indicates that of all erosive factors, the LS number has the greatest effect on the intensity of erosion, with a correlation coefficient of 1 .

The presented results indicate that it is necessary to take certain anti-erosion measures with the aim of stopping erosive processes in areas sensitive to erosion, protection of agricultural land from drifting. Proposed measures in the fight against erosion include biological-ameliorative measures (silvicultural and agromeliorative). The proposed measures of biological protection against soil erosion are: afforestation, grassing, terraced orchards and vineyards, as well as horizontal tillage. The application of the RUSLE method on the example of Bačka is determined by integrating the existing data with the GIS tool. This paper confirms the results of previous research and indicates the feasibility of the proposed approach in estimating the spatial distribution of factors in the empirical RUSLE model, the intensity of soil erosion and the interaction of land use categories with erosive conditions. In the future, the presented results can serve as an important basis in planning the use of land, as well as the selection of potentially endangered zones such as Titel loess plateau. Also, the results can be used in quantitative comparison with the results obtained by applying the EPM model in order to determine the relationship between the erosion coefficient and the erosion rate obtained by applying the RUSLE model. However, in order to improve the application of this combined method on the territory of Serbia, the results obtained in this way must be confirmed. For this reason, 
it is necessary to organize recent field measurements of the soil erosion in Bačka.

\section{Acknowledgements}

This paper represents the result of the project III43007 ("Climate Change and its effects on the Environment - Monitoring, Modeling, Adapting, Mitigating") funded by the Serbian Ministry of Education, Science and Technological Development.

\section{Conflict of Interest}

The authors declare that they have no conflict of interest.

\section{References}

1. DOULA M.K., SARRIS A. Soil Environment. In: Environment and Development: Basic Principles, Human Activities and Environmental Implications; Stavros G. Poulopoulos, Vassilis J. Inglezakis (eds.). Elsevier, 213, 2016.

2. KHALEDIAN Y., KIANI F., EBRAHIMI S., BREVIK E.C., AITKENHEAD-PETERSON J. Assessment and Monitoring of Soil Degradation during Land Use Change Using Multivariate Analysis. Land Degradation and Development, 28, 128, 2017.

3. JAYASEKARA M.J.P.T.M., KADUPITIYA H.K., VITHARANA U.W.A. Mapping of soil erosion hazard zones of Sri Lanka. Tropical Agricultural Research, 29 (2), 135, 2018.

4. GANASRI B.P., RAMESH H. Assessment of soil erosion by RUSLE model using remote sensing and GIS-a case study of Nethravathi Basin. Geoscience Frontiers, 7 (6), 953, 2016.

5. LAL R. Restoring soil quality to mitigate soil degradation. Sustainability, 7 (5), 5875, 2015. https://doi.org/10.3390/ su7055875

6. WUEPPER D., BORRELLI P., FINGER R. Countries and the global rate of soil erosion. Nature Sustainability, 3, 51, 2020. https://doi.org/10.1038/s41893-019-0438-4

7. BORRELLI P., ROBINSON D.A., FLEISCHER L.R., LUGATO E., BALLABIO C., ALEWELL C., MEUSBURGER K., MODUGNO S., SCHÜTT B., FERRO V., BAGARELLO V., VAN OOST K., MONTANARELLA L., PANAGOS P. An assessment of the global impact of $21^{\text {st }}$ century land use change on soil erosion. Nature Communications, 8, 2013, 2017.

8. Map of erosion of SR Serbia, Map size - 1: 500.000 . Institute of Forestry and Wood Industry (edited by R. Lazarević), Belgrade, 1983 [In Serbian].

9. BAUMGERTEL A., LUKIĆ S., BELANOVIĆ SIMIĆ S., KADOVIĆ R. Identifying Areas Sensitive to Wind Erosion - A Case Study of the AP Vojvodina (Serbia). Applied Sciences, 9 (23), 5106, 2019. https://doi.org/10.3390/ app9235106

10. LUKIĆ T., LUKIĆ A., BASARIN B., PONJIGER T., BLAGOJEVIĆ D., MESAROŠ M., MILANOVIĆ M., GAVRILOV M., PAVIĆ D., ZORN M., KOMAC B.,
MILJKOVIĆ Đ., SAKULSKI D., BABIĆ-KEKEZ S., MORAR C., JANIĆEVIĆ S. Rainfall erosivity and extreme precipitation in the Pannonian basin. Open Geosciences, 11 (1), 664, 2019.

11. LAZAREVIĆ R. Experimental research of water erosion intensity. Želnid: Belgrade, Serbia, 234, 2004 [In Serbian].

12. KALKAN K.S., FORKAPIĆ S., MARKOVIĆ S.B., BIKIT K., GAVRILOV M.B., TOŠIĆ R., MRĐA D., LAKATOŠ R. The application of ${ }^{137} \mathrm{Cs}$ and ${ }^{210} \mathrm{Pbex}$ methods in soil erosion research of Titel loess plateau, Vojvodina, Northern Serbia. Open Geosciences, 12 (1), 11, 2020.

13. RISTANOVIĆ B., CIMBALJEVIĆ M., MILJKOVIĆ Đ., OSTOJIĆ M., FEKETE, R. GIS Application for Determining Geographical Factors on Intensity of Erosion in Serbian River Basins. Case Study: The River Basin of Likodra. Atmosphere, 10, 526, 2019.

14. ŽIVOTIĆ LJ., PEROVIĆ V., JARAMAZ D., ĐORĐEVIĆ A., PETROVIĆ R., TODOROVIĆ M. Application of USLE, GIS, and Remote Sensing in the Assessment of Soil Erosion Rates in Southeastern Serbia. Polish Journal of Environmental Studies, 21 (6), 1929, 2012.

15. AREKHI S., SHABANI A., ROSTAMIZAD G. Application of the modified universal soil loss equation (MUSLE) in prediction of sediment yield (Case study: Kengir Watershed, Iran). Arabian Journal of Geosciences, 5, 1259, 2012. https://doi.org/10.1007/s12517-010-0271-6

16. YE H., HUA W., HUANG C., HUANG T., WANG H., YUAN X., YANG H. Quantitative Evaluation of Soil Erosion in the Upper Minjiang River Basin of China Based on Integration of Geospatial Technologies Using RUSLE. Polish Journal of Environmental Studies, 29 (5), 3419, 2020. https://doi.org/10.15244/pjoes/114260

17. KOULI M., SOUPIOS P., VALLIANATOS F. Soil erosion prediction using the Revised Universal Soil Loss Equation (RUSLE) in a GIS framework, Chania, Northwestern Crete, Greece. Environmental Geology, 57, 483, 2009.

18. GAVRILOVIĆ S. Engineering on torrent flows and erosion. Journal Construction, Special Edition, 37 (1), 292, 1972 [In Serbian].

19. EFTHIMIOU N., LYKOUDI E., PANAGOULIA D., KARAVITIS C. Assessment of soil susceptibility to erosion using the EPM and RUSLE models: the case of Venetikos River catchment. Global NEST Journal, 18 (1), 164, 2016.

20. DAVIDOVIĆ R., MILJKOVIĆ LJ., RISTANOVIC B. Relief of Bačka; Faculty of Sciences, Department of Geography, Tourism and Hotel Management: Novi Sad, Serbia, 82, 2005 [In Serbian].

21. SZYPUŁA B. Quality assessment of DEM derived from topographic maps for geomorphometric purposes. Open Geosciences, 11 (1), 843, 2019.

22. BUKUROV B. Bačka, Banat and Srem; Matica Srpska: Novi Sad, Serbia, 141, 1978 [In Serbian].

23. Census of Population, Households and Dwellings in the Republic of Serbia 2011, Population: Comparative overview of the number of population in 1948, 1953, 1961, 1971, 1981, 1991, 2002 and 2011, Data by settlements. Statistical Office of the Republic of Serbia, Belgrade, 2014 [In Serbian].

24. Survey on the Structure of Agricultural Holdings, Land. Republic Bureau of Statistics, pp. 87, Belgrade, 2019 [In Serbian].

25. RENARD K.G., FOSTER G.R., WEESIES G.A., MCCOOL D.K., YODER D.C. Predicting soil erosion by water: a guide to conservation planning with the Revised 
Universal Soil Loss Equation (RUSLE). Agriculture Handbook No. 703, USDA-ARS, 1997.

26. BENAVIDEZ R., JACKSON B., MAXWELL D., NORTON K. A review of the (Revised) Universal Soil Loss Equation ((R)USLE): with a view to increasing its global applicability and improving soil loss estimates. Hydrology Earth System Sciences, 22, 6059, 2018.

27. BISWAS S.S., PANI P. Estimation of soil erosion using RUSLE and GIS techniques: a case study of Barakar River basin, Jharkhand, India. Modelling Earth Systems and Environment, 1 (42), 2015. https://doi.org/10.1007/s40808015-0040-3

28. PANDITHARATHNE D.L.D., ABEYSINGHA N.S., NIRMANEE K.G.S., MALLAWATANTRI A. Application of Revised Universal Soil Loss Equation (Rusle) Model to Assess Soil Erosion in "Kalu Ganga" River Basin in Sri Lanka. Applied and Environmental Soil Science, Article ID $4037379,15,2019$.

29. RENARD R., FREIMUND G. Using monthly precipitation data to estimate the $\mathrm{R}$ factor in the Revised USLE. Journal of Hydrology, 157, 287, 1994.

30. PERRY M., HOLLIS D. The generation of monthly gridded datasets for a range of climatic variables over the UK. International Journal of Climatology, 25 (8), 1041, 2005.

31. ANGULO-MARTÍNEZ M., LÓPEZ-VICENTE M., VICENTE-SERRANO S.M., BEGUERÍA S. Mapping rainfall erosivity at a regional scale: a comparison of interpolation methods in the Ebro Basin (NE Spain). Hydrology Earth System Sciences, 13, 1907, 2009.

32. LEE E., AHN S., IM S. Estimation of soil erosion rate in the Democratic People's Republic of Korea using the RUSLE model. Forest Science and Technology, 13 (3), 100, 2017.

33. BENKA P., SALVAI A. GIS Soil Maps of Vojvodina for Integrated Water Resources Management. In: BALWOIS (Section 8 Information systems), Conference on Water Observation and Information System for Decision Support; Institut de Recherche pour le Developpernent, France Hydrometeorological Service of Republic of Macedonia and Hydrobiological Institute of Ohrid: Ohrid, Republic of Macedonia, 316, 2006.

34. STEWART B.A., WOOLHISER D.A., WISCHMEIER W.H., CARO J.H., FRERE M.H. Control of water pollution from cropland: volume I-a manual for guideline 1206 development, Report No. ARS-H-5-1, 111 pp., U.S. Department of Agriculture, Report No. 1207 EPA600/2-75-026a, U.S. Environmental Protection Agency, Washington, D.C., 1975.

35. WISCHMEIER W.H., SMITH D.D. Predicting rainfall erosion losses: a guide to conservation planning. United States Department of Agriculture: Washington DC, USA, pp. 51, 1978.

36. Corine Land Cover, CLC (2018). Available online: https:// land.copernicus.eu/paneuropean/corine-land-cover (retrieved 05 October 2020).

37. MORGAN R.P.C. Soil erosion and conservation, $2^{\text {nd }}$ ed; Longman: Essex, England, 198, 1995.

38. KEBEDE B., TSUNEKAWA A., HAREGEWEYN N., ADGO E., EBABU K., TSEGAYE M.D., TSUBO
M., MASUNAGA T., FENTA A.A. Determining Cand P-factors of RUSLE for different land uses and management practices across agro-ecologies: case studies from the Upper Blue Nile basin, Ethiopia. Physical Geography, 42 (2), 160, 2021.

39. QUADE D. Nonparametric partial correlation. In: Measurement in the Social Sciences; Blalock H.M. Jr (Ed.), Aldine: Chicago, USA, 369, 1974.

40. TOŠIĆ I., HRNJAK I., GAVRILOV M.B., UNKAŠEVIĆ M., MARKOVIĆ S.B., LUKIĆ T. Annual and seasonal variability of precipitation in Vojvodina. Theoretical and Applied Climatology, 117, 331, 2014. doi:10.1007/s00704013-1007-9

41. HADZIC V., KUKIN A., NESIC LJ., BELIĆ M. Influence of groundwater on pedogenetic processes of soils formed on the loess terrace of southern Bačka. In: Landscaping, Use and Preservation of Land; Dragović S. (ed.), Yugoslav Society of Soil Science: Novi Sad, Serbia, 541, 1997 [In Serbian].

42. MILJKOVIĆ H. Fundamentals of Pedology. Faculty of Science, Institute of Geography: Novi Sad, Serbia, 271, 1996 [In Serbian].

43. BUKUROV B. Physical-geographical problems of Bačka, Special Editions; Serbian Academy of Sciences and Arts: Belgrade, Serbia, 43, 209, 1975 [In Serbian].

44. LAZAREVIĆ R. Erosion in Serbia. Želnid: Belgrade, Serbia, 294, 2009 [In Serbian].

45. KOMAC B., ZORN M. Soil erosion on agricultural land in Slovenia - measurements of rill erosion in the Besnica valley. Acta Geographica Slovenica, 45 (1), 53, 2005. https://doi.org/10.3986/AGS45103

46. BLINKOV I., KOSTADINOV S., MARINOV TS.I. Comparison of erosion and erosion control works in Macedonia, Serbia and Bulgaria. International Soil and Water Conservation Research, 1 (3), 15, 2013.

47. TOŠIĆ R., KAPOVIĆ M. LOVRIĆ N., DRAGIĆEVIĆ S. Assessment of soil erosion potential using RUSLE and GIS: A case study of Bosnia and Herzegovina. Freseinus Environmental Bulletin, 22 (11a), 3241, 2013.

48. DRAGIČEVIĆ N., KARLEUŠA N., OŽANIĆ N. Modification of erosion potential method using climate and land cover parameters. Geomatics, Natural Hazards and Risk, 9 (1), 1085, 2018.

49. SPALEVIC V., BAROVIC G., VUJACIC D., CUROVIC M., BEHZADFAR M., DJUROVIC N., DUDIC B., BILLI P. The Impact of Land Use Changes on Soil Erosion in the River Basin of Miocki Potok, Montenegro. Water, 12, 2973, 2020

50. CENTERI C., JAKAB G., KERTÉSZ Á. Sheet erosion. In: Landscape Degradation in Hungary; Kertész Á (Eds.). Geographical Institute and Research Centre for Astronomy and Earth Sciences: Budapest, Hungary, pp. 15-25, 2019.

51. WALTNER I., SAEIDI S., GRÓSZ J., CENTERI C., LABORCZI A., PÁSZTOR L. Spatial Assessment of the Effects of Land Cover Change on Soil Erosion in Hungary from 1990 to 2018. ISPRS International Journal of GeoInformation, 9 (11), 667, 2020. 